\title{
Pembelajaran Sejarah pada SMAN di Daerah Terdepan, Terluar, Tertinggal (3T) Kepulauan Tanimbar Provinsi Maluku
}

\author{
Boni Marian, Umasih, Nurzengky Ibrahim \\ Universitas Negeri Jakarta \\ Email: bonimarian05@gmail.com
}

\begin{abstract}
This study aims to describe teacher preparation and the history learning process at State Senior High School in the Frontier, Outermost, and Disadvantaged Region of Tanimbar Islands. This study uses descriptive qualitative methods, using data collection techniques through observation, interviews and documentation. Informants in this study are principals, teachers and students at State Senior High School of Tanimbar Islands. The results of this study indicate that starting from preparation to the process of history learning in the State Senior High School in Tanimbar Islands has not run optimally. Facility problems negligence of school leaders, unprofessional teachers at work and lazy students are the main factors in the process of history learning in the Frontier, Outermost, and Disadvantaged Region (3T).
\end{abstract}

Keyword: Region 3T, Learning Process, History Learning

\begin{abstract}
Abstrak : Penelitin ini bertujuan untuk mendeskripsikan persiapan dan proses pembelajaran sejarah pada sekolah SMAN di Daerah Terdepan, Terluar, Tertinggal 3T. Kepulauan Tanimbar. Penelitian ini menggunakan metode kualitatif deskriptif, dengan menggunakan teknik pengumpulan data melalui obsevasi, wawancara dan dokumentasi. Informan dalam penelitian ini adalah Kepala Sekolah, Guru dan Siswa di SMAN Kepulauan Tanimbar. Hasil penelitian ini menunjukan bahwa mulai dari persiapan hingga proses pembelajaran sejarah pada SMAN di Kepulauan Tanimbar belum berjalan maksimal. Masalah fasilitas, kelalaian pimpinan sekolah, guru tidak profesional dalam bertugas dan siswa yang malas menjadi faktor utama dalam proses pembelajaran sejarah di daerah 3T.
\end{abstract}

Kata kunci : Daerah 3T, Proses Pembelajaran, Pembelajaran Sejarah

\section{PENDAHULUAN}

Salah satu ciri era globalisasi adalah semakin terkoneksi satu wilayah dengan wilayah yang lain. ketersediaan sarana dan prasarana komunikasi dan transportasi semakin mempercepat konektifitas tersebut. Tidak ada satu wilayah pun di dunia yang luput dari globalisasi termasuk Indonesia. Agar dapat bertahan dalam persaingan global, sudah tentu 
Indonesia harus memperkuat sumber daya manusianya. Hal tersebut tidaklah mudah mengingat Indonesia mempunyai wilayah yang sangat luas dan pembangunan yang belum merata di semua daerah. Daerahdaerah yang terletak di perbatasan-perbatasan, kepulauan-kepulauan ataupun yang jauh dari ibukota umumnya masih dalam kondisi terbelakang. Daerah-daerah ini sekarang disebut sebagai daerah Terdepan, Terluar, Tertinggal (3T).

Daerah Kepulauan Tanimbar Provinsi Maluku merupakan salah satu wilayah yang tergolong daerah tertinggal di Indonesia dan masuk dalam kategori 3T. Kepulauan Tanimbar berada di bagian selatan Provinsi Maluku, dan berbatasan langsung dengan negara Australia. Ketertinggalan Kepulauan Tanimbar mencangkup berbagai sektor termasuk di dalamnya bidang pendidikan. Kualitas guru, ketersediaan buku, maupun sarana dan prasarana lainnya masih sangat minim. Kondisi tersebut mengakibatkan pendidikan di Kepulauan Tanimbar masih jauh tertinggal dibandingkan dengan beberapa kabupaten kota di Provinsi Maluku. Hal ini sangat ironis, mengingat masyarakat yang hidup di Kepulauan Tanimbar sangat mengharapkan pendidikan yang layak bagi anak-anak mereka.

Masih tertinggalnya bidang pendidikan di Kepulauan Tanimbar pada gilirannya berdampak pula pada mata pelajaran sejarah. Pemahaman akan nasionalisme dan pentingnya integrasi nasional dari sisiwa-siswa SMA di daerah ini masih sangatlah minim, padahal daerah Kepulauan Tanimbar merupakan garis terdepan dalam lingkup kedaulatan Indonesia berdasarkan batas negara. Belajar sejarah berarti kita belajar untuk menguatkan rasa kepemilikan akan tanah dan air negeri 
ini dan bagaimana cara kita mengintegrasikan simpul-simpul (pulau) yang tersebar dan terpisah lautan dalam naungan NKRI. Wineburg, mengatakan bahwa sejarah memiliki potensi menjadikan manusia berperikemanusiaan, suatu hal yang tidak dapat dilakukan semua mata pelajaran. Setiap generasi harus megajukan pertanyaan mengenai mengapa penting mempelajari masa lalu dan mengingatkan dirinya sendiri mengapa sejarah dapat menyatukan manusia bukan memecahbelah (Wineburg, 2006: 6-7). Penelitian ini dengan demikian sangat penting dilakukan untuk mengetahui bagaimana pembelajaran sejarah di salah satu daerah 3T yaitu Kepulauan Tanimbar.

Dalam penelitian ini, penulis akan mengungkapkan bagaimana pembelajaran sejarah yang terjadi pada SMAN di daerah (3T) Kepulauan Tanimbar yang merupakan daerah perbatasan, sehingga sangat penting bilamana pembelajaran sejarah diperhatikan dengan serius oleh semua pihak. Menurut Hasan, ada enam tujuan mata pelajaran Sejarah Indonesia, yakni (1) Mengembangkan rasa kebangsaan, cinta tanah air, dan penghargaan terhadap hasil dan prestasi bangsa; (2) Membangun rasa kebangsaan, cinta tanah air, memahami masyarakat dan bangsa, serta menyadari keberlanjutan masa lalu dalam kehidupan masa kini, untuk membangun kehidupan masa depan yang lebih baik; (3) Membangun kesadaran peserta didik tentang pentingnya konsep waktu dan tempat/ruang dalam rangka memahami perubahan dan keberlanjutan dalam kehidupan bermasyarakat dan berbangsa di Indonesia; (4) Mengembangkan kemampuan berpikir historis (historical thinking) melalui kajian fakta dan peristiwa sejarah; (5) Menumbuhkan kesadaran dalam diri peserta didik terhadap peninggalan sejarah sebagai bukti peradaban 
bangsa Indonesia di masa lampau; dan (6) Menumbuhkan kesadaran dalam diri peserta didik sebagai bagian dari bangsa Indonesia yang memiliki rasa bangga sebagai bangsa, cinta tanah air, melahirkan empati dan perilaku toleran yang dapat diimplementasikan dalam berbagai kehidupan masyarakat dan bangsa. (Djunaedi, 2015 : 27).

Seperti yang dikemukakan oleh Hasan, bahwa lewat pembelajaran sejarah yang berkualitas, dan jika berhasil dikembangkan secara optimal dan berkelanjutan, pulau-pulau terpencil ini bukan saja akan menjadi sumber pertumbuhan baru, melainkan sekaligus akan mengurangi kesenjangan pembanngunan antar wilayah, pendidikan dan kelompok sosial. (Siregar, 2013 : 345). Harapannya adalah jangan lagi kita sebagai pegiat dalam dunia pendidikan di Indonesia masih menemukan hal-hal seperti keterbatasan sarana prasarana, sulitnya medan, rendahnya SDM siswa, serta kurangnya penghargaan terhadap guru yang mengajar menjadikan tantangan tersendiri bagi para guru di sekolah 3T yang tidak dirasakan oleh guru di daerah yang lebih maju. Guru bisa saja mengalami stres karena lingkungan kerja yang buruk dan tidak mendukung proses pembelajaran seperti minimnya sarana prasaran dan isolasi geografis. (Diah dan Pradana, $2012: 2$ ).

\section{METODE}

Metode dalam penelitian ini adalah metode kualitatif. Menurut Sugyono bahwa penelitian kualitatif deskriptif adalah metode penelitian yang berdasarkan pada filsafat postpositivisme yang formal biasanya digunakan untuk meneliti pada kondisi objektif yang alamiah dimana peneliti berperan sebagai instrumen kunci (Sugiyono. 2008 : 15). Peneliti menggunakan teknik dan prosedur pengumpulan data, dengan langkah- 
langkah observasi, wawancara, observasi adalah proses keterlibatan peneliti dalam situasi sosial, kemudian peneliti mengungkapkan seluruh apa yang dilihat, dialami dan dirasakan langsung. (Mukhtar, 2013 : 109). Wawancara yang dilakukan dalam penelitian ini adalah wawancara terstruktur dimana pewawancara atau peneliti telah menentukan format masalah atau daftar pertanyaan yang akan diwawancara berdasarkan masalah yang akan diteliti (Iskandar. 2009 : 131-132). Peneliti melakukan proses wawancara dalam penelitian ini kepada kepala sekolah, guru mata pelajaran sejarah dan siswa. Dokumentasi dalam penelitian ini, merupakan sesuatu yang sangat penting sebagai pelengkap dari metode observasi dan wawancara berupa catatan lapangan. Selain itu untuk mendapatkan data-data yang berkaitan dengan proses pembelajaran sejarah, namun juga dokumen-dokumen resmi sekolah maupun guru sejarah berupa profil sekolah SMAN di Kepulauan Tanimbar dan berbagai hal yang berkaitan dengan proses pembelajaran sejarah di Kepulauan Tanimbar.

\section{HASIL}

Persiapan guru sebelum melakukan pembelajaran sejarah pada SMAN di Daerah 3T Kepulauan Tanimbar

Lingkungan sekolah yang kurang memadai, seperti sekolah yang tidak memiliki pagar pembatas, ruang kelas yang tidak memiliki plafon, hingga lantai di ruang kelas yang masih berlubang, belum juga sumber belajar yang sangat kurang membuat guru dan siswa tidak maksimal dalam melakukan persiapan hingga proses pembelajaran. Garis koordinasi antara pemimpin di sekolah juga bermasalah, artinya kepala sekolah dan wakil kepala sekolah urusan kurikulum kurang melakukan 
supervisi dan evaluasi bahkan pembinaan kepada guru, pegawai dan siswa.

Dari masalah di atas, ternyata ini sangat berpengaruh terhadap persiapan pembelajaran yang seharusnya dibuat oleh guru. Persiapan pembelajaran yang dimakasud adalah perangkat pembelajaran seperti Silabus, RPP, Bahan Ajar dan lain sebagainya. Faktanya, selama proses pembelajaran berlangsung, tidak ada satupun guru yang menyertakan RPP dan perangkat pembelajaran lainnya di kelas. Para guru sebenarnya sudah tahu tentang tugas utama sebagai seorang guru termasuk di dalamnya kewajiban untuk membuat perangkat pembelajaran. Namun, tiga sekolah, SMAN 2 Tanimbar Selatan, SMAN Amtufu Wertamrian dan SMAN Selaru yang peneliti datangi dan melakukan peneltian, penulis tidak menemukan satupun guru sejarah yang ketika masuk kelas menyertakan perangkat pembelajaran. Berdasarkan hasil temuan peneliti guru-guru sejarah ini tidak membuat perangkat pembelajaran dikarenakan buku, contoh RPP, Silabus dan lainnya tidak difasilitasi oleh pemimpin sekolah.

Masalah yang lain adalah bahwa guru-guru sejarah ini malah memanfaatkan jam belajar untuk mengurus kantin yang ada di sekitar sekolah, mengurus anak kecil hingga dibawa ke sekolah, bahkan mengurus jualan (Kios) yang ada di perkampungan. Kerap kali guru-guru ini memanfaatkan jam sekolah untuk berbelanja bahkan mengurus anak. Ketika ditanya, alasannya sederhana, kalau aktifitas seperti ini tidak dijalankan, lantas mau makan apa, dan mau sekolahkan anak bagaimana? Guru-guru ini ternyata hanyalah guru honorer yang dibayar Rp. 
300.000.00/Bulan, yang akan dibayar per tiga bulan berjalan, itupun tidak diterima secara utuh.

Proses pembelajaran sejarah pada sekolah SMAN di Daerah 3T Kepulauan Tanimbar.

Mata pelajaran sejarah yang dari dulu dianggap membosankan, hingga kini masih saja terus seperti itu di daerah ini. Faktanya, guru yang masuk kelas tidak memiliki persiapan yang matang. Buku yang dimiliki guru, itulah yang dipakai. Buku pegangan siswa tidak ada di sebagian sekolah di daerah ini. Tuntutan kurikulum 2013, yang mengutamakan pembelajaran scientivic, tidak berjalan dengan baik. Hampir setiap jam pelajaran sejarah, guru menggunakan metode ceramah. Sesekali pembelajaran berlangsung dengan menggunakan metode berdiskusi, namun pembelajaran tidak berjalan dengan maksimal, karena siswa masih kurang sumber belajar.

Ketika kondisi kelas yang menggunakan metode diskusi kurang berjalan dengan baik, maka guru kembali menggunakan metode ceramah. Beberapa guru sebenarnya telah berusaha menerapkan metode diskusi sebagai variasi dari metode ceramah. Namun seringkali diskusi berjalan kurang lancar karena siswa kesulitan mendapat sumber belajar sehingga pada akhirnya guru terpaksa mengambil alih diskusi dan kembali menggunakan metode ceramah. Pembelajaran sejarah pun menjadi monoton apalagi dengan penguasaan materi guru yang masih minim.

Pada kesempatan lain pada jam sejarah guru tidak masuk kelas, dan hanya menitipkan buku kepada siswa sambil menentukan materi yang akan dipelajari. Buku yang dititipkan ke siswa itu nantinya akan dipercayakan salah satu siswa untuk membacanya (materi) di depan kelas, dan para siswa yang lain mencatat. Ketika ditanya, ternyata 
pembelajaran mereka setiap jam pelajaran sejarah memang seperti ini. Hal ini membuat siswa menjadi tidak betah di kelas, dan sering berkeliaran di halaman bahkan ada yang bolos sekolah. Selain itu, selama penelitian, penulis tidak pernah menemukan pembelajaran oleh guru sejarah yang menggunakan media pembelajaran.

\section{PEMBAHASAN}

Persiapan guru sebelum melakukan pembelajaran sejarah pada SMAN di Daerah 3T Kepulauan Tanimbar

Sebagian sekolah di daerah ini diketahui bahwasanya garis koordinasi antara pemimpin di sekolah bermsalah. Antara kepala sekolah dan wakasek urusan kurikulum juga tidak kompak dalam pembinaan kepada guru, pegawai dan siswa. padahal seharusnya manajemen dalam sebuah organisasi pada dasarnya dimaksudkan sebagai sesuatu proses (aktivitas) penentuan dan pencapaian tujuan organisasi dengan melaksanakan empat fungsi dasar: planning, organizing, actuating dan controlling dalam penggunaan sumberdaya organisasi. Karena itulah, aplikasi manajemen organisasi hakikatnya adalah juga amal perbuatan SDM organisasi yang bersangkutan. (Ritonga dan Ramadhani, 2014 : 8).

Selain itu, guru-guru di daerah ini terkesan tidak mengetahui atau sengaja mengabaikan tentang apa yang sudah sudah diatur dalam Undang-undang bahwasanya dalam melaksanakan tugas keprofesionalan, guru berkewajiban : Merencanakan pembelajaran, melaksanakan proses pembelajaran yang bermutu, serta menilai dan mengevaluasi hasil pembelajaran. (UU RI No.14 Tentang Guru dan Dosen, Pasal 20a). Dilanjutkan (Pasal 35: 1), bahwa beban kerja guru mencakup kegiatan pokok yaitu merencanakan pembelajaran, melaksanakan pembelajaran, menilai hasil pembelajaran, membimbing dan melatih peserta didik, serta 
melaksanakan tugas tambahan. Hal ini diperjelas oleh Nadzir, bahwasannya perencanaan pembelajaran merupakan suatu dokumen rasional yang di susun berdasarkan hasil analisis sistematis tentang perkembangan siswa dengan tujuan agar pembelajaran lebih efektif dan efisien sesuai dengan tuntutan kebutuhan para siswa dan masyarakat. Artinya guru tidak akan dapat mengajar dengan optimal apabila tidak memiliki persiapan yang dikembangkan dalam perencanaan pembelajaran (Nadzir, 2013 : 339). Lebih lengkap lagi dalam konteks pengajaran, perencanaan pembelajaran merupakan proses penyusunan materi pelajaran, penggunaan media, pendekatan dan metode pembelajaran dan penilaian dalam suatu alokasi waktu yang akan dilaksanakan mada masa tertentu untuk mencapai tujuan yang telah ditentukan, dengan dilihat dari berbagai sudut pandang antara lain seperti teknologi, suatu sistem sains, proses dan realitas (Rohman dan Amri, 2013 : 44).

Proses pembelajaran sejarah pada sekolah SMAN di Daerah 3T Kepulauan Tanimbar.

Pada bagian ini peneliti akan menguraikan apakah perangkat pembelajaran yang tidak dibuat oleh guru sejarah merupakan konsekuensi dari kurangnya upah kerja untuk guru, atau konektifitas antar pulau merupakan konsekuensi dari kurang tersedianya sumber belajar di daerah 3T ini, dan apakah tidak ada celah sedikitpun untuk keluar dari masalah ini? Sebenarnya tugas guru di kelas sangat urgent, kalau memang sumber belajar merupakan faktor penting dalam masalah proses pembelajaran, maka gurulah yang harus menjadi sumber belajar utama, dan kemudian dapat melakukan audiensi dengan berbagai pihak terkait untuk membahas masalah ini. Mengingat bahwa belajar berbasis 
sumber belajar dapat memberikan beberapa keuntungan kepada peserta didik, seperti: (1) Memungkinkan untuk menemukan bakat terpendam pada diri seseorang yang selama ini tidak tampak, (2) Memungkinkan pembelajaran berlangsung terus menerus dan belajar menjadi mudah diserap dan lebih siap diterapkan, dan (3) Seseorang dapat belajar sesuai dengan kecepatan dan dengan waktunya yang tersedia (Supriadi, 2015 : 131).

Setelah itu, untuk mewujudkannya, sudah tentu guru harus mempunyai persiapan yang matang sebelum terlibat langsung dalam pembelajaran. Persiapan dalam hal ini berupa rencana pelanksanaan pembelajaran, yang didalammnya termuat langkah-langkah pembelajaran. Langkah-langkah pelanksanaan pembelajaran ini sangat penting diterapkan dalam pembelajaran, karena di dalamnya berisikan durasi atau pengaturan waktu yang berjalan selama pembelajaran. Langkah-langkah pelaksanaan pembelajaran merupakan implementasi dari RPP, meliputi kegiatan pendahuluan, inti dan penutup (Permendikbud No 22 : 2016).

Dalam kegiatan pendahuluan, guru wajib: (a) menyiapkan peserta didik secara psikis dan fisik untuk mengikuti proses pembelajaran; (b) memberi motivasi belajar peserta didik secara kontekstual sesuai manfaat dan aplikasi materi ajar dalam kehidupan sehari-hari, dengan memberikan contoh dan perbandingan lokal, nasional dan internasional, serta disesuaikan dengan karakteristik dan jenjang peserta didik; (c) mengajukan pertanyaan-pertanyaan yang mengaitkan pengetahuan sebelumnya dengan materi yang akan dipelajari; (d) menjelaskan tujuan pembelajaran atau kompetensi dasar yang akan dicapai; dan (e) 
menyampaikan cakupan materi dan penjelasan uraian kegiatan sesuai silabus.

Kegiatan inti menggunakan model pembelajaran, metode pembelajaran, media pembelajaran, dan sumber belajar yang disesuaikan dengan karakteristik peserta didik dan mata pelajaran. Pemilihan pendekatan tematik dan /atau tematik terpadu dan/atau saintifik dan/atau inkuiri dan penyingkapan (discovery) dan/atau pembelajaran yang menghasilkan karya berbasis pemecahan masalah (project based learning) disesuaikan dengan karakteristik kompetensi dan jenjang pendidikan yang meliputi pengetahuan, sikap, dan keterampilan.

Pengetahuan dimiliki melalui aktivitas mengetahui, memahami, menerapkan, menganalisis, mengevaluasi, hingga mencipta. Karakteritik aktivititas belajar dalam domain pengetahuan ini memiliki perbedaan dan kesamaan dengan aktivitas belajar dalam domain keterampilan. Untuk memperkuat pendekatan saintifik, tematik terpadu, dan tematik sangat disarankan untuk menerapkan belajar berbasis penyingkapan/penelitian (discovery/inquiry learning). Untuk mendorong peserta didik menghasilkan karya kreatif dan kontekstual, baik individual maupun kelompok, disarankan yang menghasilkan karya berbasis pemecahan masalah (project based learning).

Sesuai dengan karakteristik sikap, maka salah satu alternatif yang dipilih adalah proses afeksi mulai dari menerima, menjalankan, menghargai, menghayati, hingga mengamalkan. Seluruh aktivitas pembelajaran berorientasi pada tahapan kompetensi yang mendorong peserta didik untuk melakuan aktivitas tersebut. 
Keterampilan diperoleh melalui kegiatan mengamati, menanya, mencoba, menalar, menyaji, dan mencipta. Seluruh isi materi (topik dan sub topik) mata pelajaran yang diturunkan dari keterampilan harus mendorong peserta didik untuk melakukan proses pengamatan hingga penciptaan. Untuk mewujudkan keterampilan tersebut perlu melakukan pembelajaran yang menerapkan modus belajar berbasis penyingkapan/penelitian (discovery/inquiry learning) dan pembelajaran yang menghasilkan karya berbasis pemecahan masalah (project based learning).

Dalam kegiatan penutup, guru bersama peserta didik baik secara individual maupun kelompok melakukan refleksi untuk mengevaluasi: (a) seluruh rangkaian aktivitas pembelajaran dan hasil-hasil yang diperoleh untuk selanjutnya secara bersama menemukan manfaat langsung maupun tidak langsung dari hasil pembelajaran yang telah berlangsung; (b) memberikan umpan balik terhadap proses dan hasil pembelajaran; (c) melakukan kegiatan tindak lanjut dalam bentuk pemberian tugas, baik tugas individual maupun kelompok; dan (d) menginformasikan rencana kegiatan pembelajaran untuk pertemuan berikutnya.

Setelah itu, guru bisa saja mengeksplorasikan kelas dengan berbagai macam strategi, dan menggunakan media pembelajaran, guna membuat proses pembelajaran semakin beragam dan kontekstual. Seperti sudah dijelaskan bahwa media pembelajaran mempunyai kegunaan seperti (1) memperjelas pesan agar siswa tidak terlalu variabelitas, (2) mengatasi keterbatasan ruang, (3) menimbulkan gairah belajar, (4) memungkinkan anak belajar mandiri sesuai dengan bakat dan kemampuan yang dimilliki dan (5) memberikan rangsangan yang sama, 
mempersamakan pengalaman dan menimbulkan persepsi yang sama. (Rohman dan Amri, 2013 : 130).

Dengan demikian, lewat suatu pembelajaran terencana dengan baik, sebagaimana yang tercantum dalam Pasal 19 PP No 19 tahun 2005, bahwa proses pembelajaran pada satuan pendidikan diselenggarakan secara interaktif, inspiratif, menyenangkan, menantang dan memotivasi siswa untuk berpartisipasi aktif, serta memberikan ruang yang cukup bagi prakarsa, kreatifitas dan kemandirian sesuai dengan bakat, minat dan perkembangan fisik serta psikologis siswa (PP No. 19, 2005 : Ps. 19).

\section{KESIMPULAN}

Kepemimpinan sekolah pada SMAN di daerah 3T Kepulauan Tanimbar sangat berpengaruh dalam aktifitas pembelajaran di sekolah. Antara kepala sekolah dan wakil kepala sekolah kurang memperhatikan, mengayomi dan mendidik guru, pegawai dan siswa. Kelengkapan administrasi terkait persiapan hingga proses pembelajaran jarang diperiksa dan dievaluasi. Guru terlena dengan keadaan yang ada, sehingga tugas utama sebagai guru tidak dijalangkan dengan maksimal. Persiapan perangkat pembelajaran sejarah kurang maksimal, berpengaruh terhadap proses pembelajaran sejarah yang tidak berjalan maksimal. Di kelas, guru tidak memiliki kelengkapan akan perangkat pembelajaran, mulai dari Silabus, RPP, Bahan Ajar, Media Pembelajaran, LKS/LKPD hingga Penilaian. Proses pembelajaran di kelas terjadi secara monoton, bahkan terkadang siswa belajar sendiri tanpa pengawasan dengan cara mencatat buku pelajaran yang dititipkan oleh guru. Hal ini yang dimanfaatkan oleh siswa untuk berkeliaran di luar kelas hingga membolos dari sekolah. 


\section{DAFTAR PUSTAKA}

[1] Djunaedi, "Strategi Pengelolaan Pembelajaran Isu Materi Sejarah "Serupa" dan Sejarah Kontroversial". Jurnal Pendidikan Sejarah, Vol. 4 No. 2 Juli 2015.

[2] Iskandar, (2009), Metodologi Penelitian Kualitatif. Jakarta: Gaung Perseda.

[3] Rohman, Muhamad dan Sofan Amri. (2013). Strategi Dan Desain Pengembaangan Sistem Pembelajaran. Jakarta: Prestasi Pustaka.

[4] Mukhtar. (2013). Metode Praktis Penelitian Deskriptif Kualitatif. Jakarta: Referensi.

[5] Hamid, Palima. (2007). Metode Penelitian Kualitatif. Bandung: Alfabeta.

[6] Peraturan Menteri Pendidikan Dan Kebudayaan Nomor 22 Tahun 2016 Tentang Standar Proses Pendidikan Dasar Dan Menengah

[7] Peraturan Pemerintah Republik Indonesia Nomor 19 Tahun 2005 Tentang Standar Nasional Pendidikan

[8] Pramesti, Pradana P. dan Risa Diah A.K. “Resiliensi Di Sekolah Terpencil”. Jurnal Psikologi Perkembangan Vol. 1, No 02, 2012.

[9] Ritonga, Rudi dan Sulistyani Puteri Ramadhani. (2014). Manajemen Pendidikan, Konsep Dan Aplikasi Pengembangan Pendidikan. Jakarta : LPBM.

[10] Chairil N., Siregar."Analisis Potensi Daerah Pulau-Pulau Terpencil Dalam Rangka Meningkatkan Ketahanan, Keamnanan Nasional, Dan Keutuhan Wilayah NKRI Di Nunukan-Kalimantan Utara". Ejurnal Sosioteknologi Edisi 13, 2013. 
[11] Sugiyono. (2008). Metode Peneliian Pendidikan Kuantitatif, Kualitatif, dan RED. Bandung: Alfabeta.

[12] Undang-undang Republik Indonesia No.14 Tentang Guru Dan Dosen

[13] Wineburg, Sam. (2006). Berpikir Historis: Memetakan Masa Depan Mengajarkan Masa Lalu. Jakarta: Yayasan Obor Indonesia. 